\title{
PANCASILA SEBAGAI FILSAFAT ILMU DAN IMPLIKASI TERHADAP PENGEMBANGAN ILMU PENGETAHUAN DAN TEKNOLOGI
}

\author{
Syarifuddin \\ Fakultas Tarbiyah IAI Muhammadiyah Bima \\ syarifpps@gmail.com
}

\begin{abstract}
Abstrak
Artikel ini menjabarkan tentang pancasila sebagai filsafat ilmu dan implikasinya pada perkembangan ilmu pengetahuan dan teknologi. Pancasila merupakan falsafah dan pedoman hidup bangsa indonesia dari hasil pemikiran yang mendalam yang dilakukan oleh anak bangsa. Perkembangan ilmu pengetauan saat ini dan di masa yang akan datang sangat cepat di berbagai lini kehidupan berbangsa dan bernegara, memasuki dan mempengaruhi segala aspek kehidupan adat dan budaya bangsa. Perkembangan Ilmu Pengetahuan dan Tekhnologi yang tidak dibarengi dengan dasar-dasar Pancasila yang kuat justru akan menjadi aspek penghancur bangsa, terutama dari segi moralitas dan mentalitas. Perkembangan ilmu pengetahuan dan tekhnologi yang terlampau deras menyebabkan terlalu mudahnya informasi dari seluruh penjuru dunia masuk ke dalam bangsa kita, sehingga penting kiranya memperkuat warga Negara menanamkan nilai-nilai pancasila sebagai dasar dalam memahami dan mengembangkan ilmu pengetahuan dan teknologi.
\end{abstract}

Kata Kunci: Pancasila, Filsafat Ilmu, Ilmu pengetahuan dan Teknologi

\section{PENDAHULUAN}

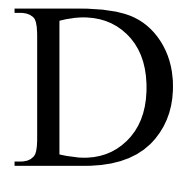

ewasa ini di Indonesia, banyak berkembang pandanganpandangan ideologi yang mempertanyakan keberadaan pancasila sebagai sistem ideologi bangsa Indonesia. Pandangan ideologi disampaikan oleh golongan-golongan tertentu yang menginginkan perubahan bentuk pemerintahan. Keinginan tersebut tidak serta merta dapat merubah bentuk pemerintahan Negara Kesatuan Republik Indonesia (NKRI) yang telah dirumuskan para pendirinya. Keberadaan negara Indonesia diperjuangkan oleh perintis perjuangan bangsa yang memakan waktu yang sangat lama. Pejuang-pejuang local di seluruh daerah hampir 
tak pernah putus melakukan perlawanan terhadap penjajah.

Panjangnya perjuangan kemerdekaan bangsa Indonesia, sudah seharusnya kita mempertahankan kemerdekaan bangsa ini dengan mengisinya dengan pembangunan. Para pengada negara Indonesia telah merumuskan dasar-dasar ideologi bangsa dengan jalan musyawah dan mufakat. Perumusan dasar negara telah digali oleh para pengada negara Indonesia dari berbagai macam unsur yang ada di nusantara. Berbagai macam unsur tersebut tersarikan dalam wujud Pancasila. Pancasila sebagai dasar negara bangsa Indonesia telah bersifat final, sehari setelah Proklamasi kemerdekaan dibacakan oleh Soekarno dan Hatta. Pancasila harus menjadi dasar dalam pengembangan ilmu dan teknologi. Perkembangan ilmu pengetauan saat ini dan di masa yang akan datang sangat cepat di berbagai lini kehidupan berbangsa dan bernegara memasuki dan mempengaruhi segala aspek kehidupan adat danbudaya bangsa. Perkembangan Ilmu Pengetahuan dan Tekhnologi yang tidak dibarengi dengan dasar-dasar Pancasila yang kuat justru akan menjadi aspek penghancur bangsa, terutama dari segi moralitas dan mentalitas.

Perkembangan tekhnologi yang terlampau deras menyebabkan terlalu mudahnya informasi dari seluruh penjuru dunia masuk ke dalam bangsa kita. Segala kemudahan dalam berinteraksi juga semakin tidak dapat dibendung lagi. Hal tersebut didukung dengan adanya perkembangan media informasi yang menyediakan layanan-layanan dan berbagai fasilitas canggih untuk berkomunikasi. Sesungguhanya semua kemajuan ini sangat membantu dan meringankan kita dalam melakukan aktivitas. Pekerjaan akan semakin cepat terselesaikan dan menghemat waktu serta tenaga. Kini tiada lagi jarak yang berarti dalam bertukar informasi. Kehidupan di dalam masyarakat semakin nyaman dan menyenangkan. Masyarakat madani pun akan semakin mudah tercapai, walaupun di sisi lain hal ini merupakan suatu tantangan bagi bangsa kita untuk dapat mengikuti perkembangan dan kemajuan tekhnologi. Sebab tak kan tercipta masyarakat madani apabila perkembangan dan kemajuan tekhnologi kita masih terbelakang dan hanya 
bertumpu kepada bangsa asing. Maka sangat penting pancasila sebagai pegangan atau pedoman untuk filter berbagai perkembangan ilmu pengetahuan dan tekhnologi yang ada saat ini.

\section{Konsep Dasar Pancasila}

Pancasila adalah ideologi dasar bagi negara Indonesia. Nama ini terdiri dari dua kata dari Sanskerta : panca berarti lima dan sila berarti prinsip atau asas. Pancasila merupakan rumusan dan pedoman kehidupan berbangsa dan bernegara bagi seluruh rakyat Indonesia. Menurut Muhammad Yamin bahwa Pancasila berasal dari kata Panca yang berarti lima dan Sila yang berarti sendi, atas, dasar atau peraturan tingkah laku yang penting dan baik. Dengan demikian Pancasila merupakan lima dasar yang berisi pedoman atau aturan tentang tingkah laku yang penting dan baik, sedangkan pendapatnya Notonegoro bahwa pancasila adalah dasar falsafah negara indonesia, sehingga dapat diambil kesimpulan bahwa Pancasila merupakan dasar falsafah dan ideologi negara yang diharapkan menjadi pandangan hidup bangsa Indonesia sebagai dasar pemersatu, lambang persatuan dan kesatuan serta sebagai pertahanan bangsa dan negara Indonesia (Burhanudin S, 1988).

Pancasila merupakan falsafah dan pedoman hidup bangsa indonesia dari hasil pemikiran yang mendalam yang dilakukan oleh anak bangsa. menurut Soekarno pancasila adalah isi jiwa bangsa Indonesia yang turuntemurun sekian abad lamanya terpendam bisu oleh kebudayaan Barat. Dengan demikian, Pancasila tidak saja falsafah negara, tetapi lebih luas lagi, yakni falsafah bangsa Indonesia(Sunoto, 1991). Pancasila merupakan hasil dari berbagai macam pemikiran yang lahir dari budaya nusantara. Sukusuku bangsa di nusantara telah melakukan akulturasi antar suku bangsa, antar bangsa sehingga terbentuklah kepribadian kebudayaan bangsa. Akulturasi budaya terus berkembang hingga abad ke 16 ketika bangsa Eropa masuk ke Indonesia dan mulai melakukan usaha penjajahan. Pada masa penjajahan, bangsa Indonesia banyak mengalami berbagai macam akulturasi budaya, ekonomi, politik, pendidikan hingga pengetahuan. Anak bangsa 
mengalami perkembangan pengetahuan saat dicetuskannya politik etis oleh van Deventer. Politik etis yang diterapkan oleh pemerintah Hinddia Belanda membawa pengaruh yang sangat besar bagi lahirnya para pemikir bangsa. Kelahiran para pemikiri sekaligus pengada Indonesia terlahir dari berbagai macam latar belakang pendidikan dan suku bangsa. Pemikiran dan pengetahuan yang berasal dari Eropa, Timur Tengah, Asia, dan lokal membahur menjadi satu, pemikiran pembentukan negara Indonesia. Pengetahuan dan pemikiran dari berbagai macam arah, terwujud pada rumusan Pancasila dan Undang-Undang Dasar 1945.

Berdasarkan berbagai pendapat di atas dapat disimpulkan bahwa pancasila adalah pedoman atau aturan tentang tingkah laku yang penting dan baik dan juga sebagai dasar falsafah negara indonesia yang lahir dari pemikiran mendalam yang dilakukan oleh anak bangsa dengan tujuan untuk dijadikan pandangan hidup bangsa Indonesia sebagai dasar pemersatu, lambang kesatuan serta sebagai pertahanan bangsa dan negara Indonesia.

\section{Pancasila sebagai Filsafat Ilmu}

Sebagaimana dijelaskan sebelumnya bahwa pancasila merupakan pedoman atau petunjuk dalam hidup berbangsa dan bernegara yang merupakan hasil dari proses berpikir yang mendalam yang dilakukan oleh anak bangsa berdasarkan nilai-nilai budaya nusantara. Pancasila merupakan dasar falsafah dan ideologi negara yang diharapkan menjadi pandangan hidup bangsa Indonesia sebagai dasar pemersatu, lambang persatuan dan kesatuan serta sebagai pertahanan bangsa dan negara Indonesia. Menurut Friedrich Hegel bahwa hakekat filsafat ialah satu sinthese fikiran yang lahir dari pada antithese fikiran. Dari pertentangan fikiran lahirlah perpaduan pendapat yang harmonis. Begitu pulalah dengan ajaran pancasila, satu sinthese Negara yang lahir dari pada satu antithese. (Sunoto, 1991), sedangkan menurut Muhtar Filsafat dapat diartikan sebagai suatu sikap seseorang yang sadar dan dewasa dalam memikirkan segala sesuatu secara mendalam, dan ingin melihat dari segala segi yang luas dan menyeluruh dengan segala hubungan (Muhtar Latif, 2014). 
Berdasarkan beberapa pendapat di atas dapat disimpulkan bahwa pancasila merupakan bagian dari filsafat ilmu. Pancasila sebagai filsafat ilmu merupakan landasan dalam proses berfikir dan berpengetahuan. Sebuah pengetahuan dalam perkembangannya harus memperhatikan aspek Ketuhanan yang merupakan landasan dalam setiap berfikir manusia. Pengetahuan harus memperhatikan aspek kemanusiaan, tanpa memperhatikan landasasan ini, pengetahuan akan terlepas dari nilai-nilai hakiki pengetahuan itu. Pancasila ada karena suatu proses pembentukan pengetahuan dari berbagai sumber yang kemudian terakumulasi dalam kehidupan sehari-hari. Pancasila sebagai filsafat ilmu didalam mengadakan pemikiran yang sedalam-dalamnya, tidak hanya bertujuan mencari kebenaran dan kebijaksanaan, tidak sekedar untuk memenuhi hasrat ingin tahu dari manusia yang tidak habis-habisnya, tetapi juga dan terutama hasil pemikiran yang berwujud filsafat pancasila tersebut dipergunakan sebagai pedoman hidup sehari-hari (pandangan hidup, filsafat hidup, way of life, dan sebagainya) dan juga sebagai pedoman pengembangan ilmu pengetahuan agar hidunya dapat mencapai kebahagiaan lahir dan batin, baik di dunia maupun di akhirat. (Burhanudin S, 1988).

Pancasila sebagai suatu sistem filsafat pada hakikatnya adalah suatu sistem pengetahuan. Dalam kehidupan sehari-hari Pancasila menjadi pedoman atau dasar bagi bangsa Indonesia dalam memandang realitas alam semesta, manusia, masyarakat, bangsa, dan negara tentang makna hidup serta sebagai dasar bagi manusia Indonesia untuk menyelesaikan masalah yang dihadapi dalam hidup dan kehidupan. Pancasila sebagai filsafat ilmu mengandung nilai ganda, yaitu harus memberikan landasar teoritik (dan normatif) bagi penguasaan dan pengembangan iptek dan menetapkan tujuan; dan nilai instrinsik tujuan iptek dilandasi oleh nilai mental kepribadian dan moral manusia (Syam, 2006). Pancasila sebagai filsafat ilmu memungkinkan masyarakat dapat memikirkan masalah-masalah dasar hidupnya secara rasional dengan bahasa, wawasan dan argumentasi yang universal. Dengan demikian, Pancasila sebagai filsafat dapat membuka 
cakrawala bagi diskusi secara terbuka terhadap masalah-masalah dan sekaligus secara kritis terhadap penyempitan-penyempitan ideologis. Pancasila sebagai filsafat juga akan membantu kita untuk mengambil sikap terbuka dan kritis terhadap dampak modernisasi dan menjadi pemain aktif, mempertahankan identitas sebagai bangsa Indonesia. Pancasila sebagai filsafat ilmu dalam perkembangan ilmu pengetahuan diharapakan dapat memecahkan permasalahan dalam kehidupannya. Pancasila sebagai ilmu pengetahuan harus dikembangkan demi ilmu pengetahuan. Ilmu pengetahuan juga harus dapat menjawab berbagai persoalan hidup. Pancasila yang terdiri dari lima sila, merupakan bentuk akumulasi proses pemecahan masalah kehidupan bangsa Indonesia dalam kehidupan seharihari, berbangsa dan bernegara.

\section{Implikasi sila-sila dalam Pengembangan IPTEK}

\section{Ketuhanan yang maha esa}

Ketuhanan berasal dari kata Tuhan ialah pencipta segala yang ada dan semua mahluk. Yang maha esa berarti maha tunggal, tiada sekutu, Esa dalam Zatnya, Esa dalam sifatnya, Esa dalam perbuatannya, artinya bahwa zat Tuhan tidak terdiri dari zat yang banyak lalu menjadi satu, bahwa sifat Tuhan adalah sesempurna-sempurnanya. Bahwa perbuatan Tuhan tidak dapat disamai oleh siapa pun. Jadi ketuhanan yang Maha Esa mengandung pengertian dan keyakinan adanya Tuhan Yang Maha Esa, pencipta alam semesta beserta isinya (Burhanudin, 1988). Adapun Nilai-Nilai Pancasila Menurut Soedjadi pada sila KeTuhanan yang maha Esa adalah:

a. Percaya dan takwa kepada Tuhan yang maha Esa sesuai dengan agama dan kepercayaan masing-masing menurut dasar kemanusiaan yang adil dan beradab.

b. Hormat menghormati dan berkerjasama antara pemeluk agama dan penganut kepercayaan yang berbeda-beda, sehingga terbina kerukunan hidup.

c. Saling menghormati kebebasan menjalankan ibadah sesuai dengan 
agama dan kepercayaannya.

d. Tidak memaksakan suatu agama dan kepercayaan kepada orang lain.

Sedangkan menurut Muchtar Nilai-Nilai di dalam sila Ketuhanan yang Mahasa Esa terkandung nilai Religius antara lain adalah:

a. Kepercayaan Terhadap adanya Tuhan Yang Maha Esa sebagai pencipta segala sesuatu dengan sifat-sifat yang sempurna dan suci seperti Mahakuasa, Maha Adil, Maha Bijaksana, dan sebagainya;

b. Ketakwaan Terhadap Tuhan yang Maha Esa, yakni menjalankan semua perintah-Nya dan menjauhi segala larangan-Nya. (Prasetio P, 2014)

Implikasi Sila I Ketuhanan Yang Maha Esa dalam pengembangan ilmu pengetahuan Manusia pada hakikatnya adalah mahluk religi. Sebagai mahluk religi, setiap manusia memiliki potensi untuk sampai pada kesadaran bahwa terdapat kekuatan, dengan segala kemahaan, yang mencipta dan menguasai jagad raya. (Toenlie,2014) Dalam Pengembangan Ilmu pengetahuan, sangat perlu dilakukan penanaman nilai religi mulai dari pendidikan dasar, sampai pada pendidikan Tinggi. Dalam Pengembangan ilmu pengetahuan manusia perlu memahami batas kemampuannya dalam berfikir, karena tidak semua yang ada di alam ini mampu dijangkau oleh pemikiran manusia, dari keterbatasan kemampuan tersebut manusia harus mengembalikan kepada sang Pencipta dan penguasa segala sesuatu yang ada di alam ini, Sehingga dalam pengembangan ilmu pengetahuan, manusia harus menciptakan perimbangan antara yang rasional dan irrasional, antara rasa dan akal. Sila Ketuhanan Yang Maha Esa ini menempatkan manusia dalam alam ini sebagai bagiannya dan bukan sebagai pusatnya, Tuhanlah sebagai pusatnya bukanlah manusia.

Menanamkan nilai- nilai spiritual, nilai Moral dan nilai etik sesuai dengan Agama dan Kepercayaan masing-masing dan juga menumbuhkan kesadaran Beragama dengan Mejalankan Perintah-Nya dan menjauhi segala Larangan-Nya melalui kurikulum Mata pelajaran Agama. Menanamkan sikap saling hormat menghormati dan berkerjasama antara pemeluk agama dan penganut kepercayaan yang berbeda-beda, sehingga terbina kerukunan 
hidup, Saling menghormati kebebasan menjalankan ibadah sesuai dengan agama dan kepercayaannya dan tidak memaksakan suatu agama dan kepercayaan kepada orang lain. Dalam hal ini melalui mata Pelajaran PPKN atau Mata Kuliah Pancasila. Mencakup tanggung jawab bersama dari semua kelompok dan golongan beragama dan kepercayaan kepada Tuhan Yang Maha Esa untuk secara terus menerus dan bersama-sama meletakkan landasan spiritual, Moral dan Etik yang kukuh bagi pembangunan Nasional sebagai pengamalan pancasila.

\section{Kemanusiaan yang adil dan beradab}

Kemanusiaan berasal dari kata manusia, yaitu mahluk yang berbudi, yang memiliki Potensi Pikir, rasa karsa dan cipta. Karena Potensi ini manusia menduduki martabat yang paling tinggi. Dengan akal budinya manusia menjadi kebudayaan, dengan budi murninya manusia menyadari nilai-nilai dan norma-norma. Kemanusiaan terutama berarti sifat manusia yang merupakan esensial dan identitatas manusia karena martabat kemanusiaanya. Adil terutama berarti bahwa suatu keputusan dan tindakan didasarkan atas norma-norma yang obyektif, bukan subyektif apa lagi sewenang-wenang. Beradab berasal dari kata adab yang berarti budaya. Jadi beradab berarti berbudaya, ini berarti bahwa sikap hidup, keputusan dan tindakan manusia selalu berdasarkan nilai-nilai budaya, terutama norma social dan norma kesusilaan atau moral. (Burhanudin, 1988).

Jadi kemanusiaan yang adil dan beradab adalah kesadaran sikap dan perbuatan manusia yang didasarkan kepada potensi budi murni manusia dalam hubungan dengan norma-norma dan kebudayaan umum baik terhadap diri pribadi, sesama manusia maupun terhadap alam dan hewan. Pada prinsipnya kemanusiaan yang adil dan beradab adalah sikap dan perbuatan manusia yang sesungguhnya sesuai dengan kodrat hakikat manusia yang berbudi, sadar nilai dan berbudaya. Adapun nilai-nilai yang terkandung di dalam sila yang kedua Menurut Soejadi adalah:

a. Mengakui persamaan derajat, persamaan hak dan persamaan kewajiban antara sesame manusia. 
b. Saling mencintai sesame manusia.

c. Mengembalikan sikap tenggang rasa

d. Tidak semena-mena terhadap orang lain

e. Menjunjung tinggi nilai kemanusiaan

f. Gemar melakukan kegiatan kemanusiaan

g. Berani membela kebenaran dan keadilan

h. Bangsa indonesia merasa dirinya bagian dari seluruh umat manusia, karena itu dikembangkan sikap hormat-menghormati dan bekerjasama dengan bangsa lain.

Sedangkan menurut Mochtar sila ke tiga mengandung nilai kemanusiaan, antara lain:

a. Pengakuan terhadap harkat dan martabat manusia dengan segala hak dan wajib asasinya.

b. Perlakuan yang adil terhadap sesama manusia, terhadap diri sendiri, alam sekitar, dan terhadap Tuhan.

c. Manusia sebagai mahluk beradab atau berbudaya yang memilki daya cipta, rasa, karsa, dan keyakinan.

Implikasi Sila Kemanusiaan yang adil dan beradab dalam pengembangan ilmu pengetahuan adalah memberi arah dan mengendalikan ilmu pengetahuan. Ilmu dikembalikan pada fungsinya semula, yaitu untuk kemanusiaan, tidak hanya untuk kelompok, lapisan tertentu. Sila kemanusiaan yang adil dan beradab juga memberikan dasar-dasar moralitas bahwa manusia dalam mengembangkan ilmu pengetahuan haruslah secara beradab. Iptek adalah bagian dari proses budaya manusia yang beradab dan bermoral. Oleh karena itu, pembangunan iptek harus berdasarkan kepada usaha-usaha mencapai kesejahteraan umat manusia. Iptek harus dapat diabadikan untuk peningkatan harkat dan martabat manusia, bukan menjadikan manusia sebagai makhluk yang angkuh dan sombong akibat dari penggunaan IPTEK. 


\section{Persatuan Indonesia}

Persatuan berasal dari kata Satu, yang berarti utuh tidak pecah belah, persatuan mengandung pengertian bersatunya bermacam corak yang beraneka ragam menjadi satu kebulatan. Jadi persatuan Indonesia ialah persatuan Indonesia yang mendiami wilayah Indonesia. Bangsa ini bersatu karena didorong untuk mencapai kehidupan yang bebas dalam wadah Negara yang merdeka dan berdaulat. Persatuan Indonesia, bertujuan memajukan kesejahteraan umum dan mencerdaskan kehidupan bangsa serta mewujudkan perdamaian yang abadi. Persatuan Indonesia adalah perwujudan dari pada paham kebangsaan Indonesia yang dijiwai oleh Ketuhanan yang Maha Esa serta kemanusiaan yang adil dan beradab. (Burhanudin, 1988). Adapun nilai-nilai pada sila ke 3 adalah

a. Pengakuan terhadap bhineka Tunggal Ika suku bangsa, etnis, agama, adat Istiadat dan kebudayaan.

b. Pengakuan terhadap persatuan bangsa dan wilayah indonesia serta wajib membela dan menjunjung tingginya (Patriotisme).

c. Cinta dan bangga akan bangsa dan Negara Indonesia (Nasionalisme).

Implikasinya dalam pengembangan ilmu pengetahuan adalah Sila persatuan Indonesia, memberikan kesadaran kepada bangsa Indonesia bahwa rasa nasionalisme bangsa Indonesia akibat dari sumbangan iptek, dengan iptek persatuan dan kesatuan bangsa dapat terwujud dan terpelihara, persaudaraan dan pesahabatan antar daerah di berbagai daerah terjalin karena tidak lepas dari factor kemajuan iptek. Oleh sebab itu, iptek harus dapat dikembangkan untuk memperkuat rasa persatuan dan kesatuan bangsa dan selanjutnya dapat dikembangkan dalam hubungan manusia Indonesia dengan masyarakat internasional.

\section{Kerakyatan yang dipimpin oleh Hikmat Kebijaksanaan dalam permusyawaratan perwakilan}

Kerakyatan yang berasal dari kata rakyat, yang berarti sekelompok manusia yang berdiam dalam satu wilayah tertentu. Kerakyatan dalam hubungan sila IV ini berarti bahwa kekuasaan yang tertinggi berada di 
tangan rakyat. Kerakyatan disebut Pula kedaulatan rakyat (rakyat berdaulat/berkuasa) atau demokrasi (rakyat yang memerintah). Hikmat kebijaksanaan berarti penggunaan rasio/akal yang sehat dengan selalu mempertimbangkan persatuan dan kesatuan bangsa, kepentingan rakyat, dan dilaksanakan dengan sadar, jujur dan bertanggung jawab serta didorong oleh itikad baik sesuai dengan hati nurani manusia.

Permusyawaratan adalah suatu tata cara khas kepribadian Indonesia untuk merumuskan dan atau memutuskan sesuatu hal berdasarkan kehendak rakyat, sehingga tercapai keputusan yang berdasarkan kebulatan pendapat/mufakat. Perwakilan adalah suatu system dalam arti kata cara mengusahakan ikut sertanya rakyat mengambil bagian dalam kehidupan bernegara, antara lain dilakukan dengan melalui basan-badan perwakilan. (Burhanudin, 1988). Jadi kerakyatan yang dipimpin oleh hikmat kebijaksanaan dalam permusywaratan perwakilan" berarti bahwa rakyat dalam menjalankan kekuasaannya melalui system perwakilan dari keputusan-keputusannya diambil dengan jalan musyawarah yang dipimpin oleh pikiran yang sehat serta penuh tanggung jawab, baik kepada Tuhan Yang Maha Esa maupun kepada rakyat yang diwakilinya. Sila keempat ini merupakan sendi yang penting dari pada asas kekeluargaan masyarakat kita dan juga merupakan suaru azas bahwa tata pemerintahan Republik Indonesia didasarkan atas dasar kedaulatan rakyat. Adapun nilai-nilai dalam sila ke 4 sebgai berikut:

a. Negara adalah untuk kepentingan seluruh rakyat.

b. Kedaulatan adalah ditangan rakyat

c. Manuasia indonesia adalah sebagai warga Negara dan warga masyarakat mempunyai kedudukan, hak dan kewajiban yang sama.

d. Pimpinan kerakyatan adalah hikmat kebijaksanaan yang dilandasi akal sehat.

e. Keputusan yang diambil berdasarkan musyawarah untuk mufakat oleh wakil-wakil rakyat. 
Implikasinya dalam pengembangan pengetahuan adalah Sila kerakyatan yang dipimpin oleh hikmat kebijaksaan dalam permusyawaratan perwakilan, mendasari pengembangan Iptek secara demokratis. Artinya, setiap ilmuwan haruslah memiliki kebebasan untuk mengembangkan Iptek. Selain itu dalam pengembangan iptek setiap ilmuwan juga harus menghormati dan menghargai kebebasan orang lain dan harus memilki sikap yang tebuka artinya terbuka untuk dikritik/dikaji ulang maupun dibandingkan dengan penemuan teori lainnya.

\section{Keadilan Sosial Bagi Seluruh Rakyat Indonesia.}

Keadilan berasal dari kata adil, yang berarti keadilan yang berlaku dalam masyarakat disegala bidang kehidupan, baik material maupun spiritual. Seluruh rakyat Indonesia berarti setiap orang yang menjadi rakyat Indonesia, baik yang berdiam di bawah kekuasaan maupun warga Indonesia yang berdiam di luar negeri. (Burhanudin, 1988). Jadi keadilan social bagi seluruh rakyat Indonesia berarti bahwa setiap orang Indonesia mendapat perlakuan yang ada dalam bidang hukum, politik, ekonomi, dan kebudayaan. Adapun nilai-nilai sila ke 5 adalah:

a. Perlakuan yang adil disegala bidang kehidupan terutama dibidang politik, ekonomi, social dan budaya.

b. Perwujudan keadilan sosial itu meliputi seluruh rakyat Indonesia.

c. Keseimbangan antara hak dan kewajiban.

d. Menghormati hak milik orang lain

e. Cita-cita masyarakat yang adil dan makmur yang merata material dan spiritual bagi seluruh rakyat indonesia.

f. Cinta akan kemajuan dan pembangunan.

Implikasi sila ke 5 dalam pengembangan ilmu pengetahuan adalah; Sila keadilan sosial bagi seluruh rakyat Indonesia, mengimplementasikan pengembangan iptek haruslah menjaga keseimbangan keadilan dalam kehidupan kemanusiaan yaitu keseimbangan keadilan dalam hubungannya dengan dirinya sendiri, manusia dengan Tuhannya, manusia dengan 
manusia lain, manusia dengan msyarakat bangsa dan negara serta manusia dengan alam lingkungannya (T. Jacob, 1986).

\section{SIMPULAN}

Pancasila merupakan dasar negara Republik Indonesia yang terumuskan dari proses akulturasi budaya nusantara yang berlangsung berabad-abad. Dalam kehidupan sehari-hari Pancasila menjadi pedoman atau dasar bagi bangsa Indonesia dalam memandang realitas alam semesta, manusia, masyarakat, bangsa, dan negara tentang makna hidup serta sebagai dasar bagi manusia Indonesia untuk menyelesaikan masalah yang dihadapi dalam hidup dan kehidupan. Pancasila sebagai filsafat ilmu merupakan landasan dalam proses berfikir dan berpengetahuan. Berangakat dari pemikiran tersebut, maka pengembangan ilmu pengetahuan yang didasarkan pada nilai-nilai Pancasila diharapkan dapat membawa perbaikan kualitas hidup manusia indonesia dan kehidupan masyarakat yang sejahtera, aman dan damai.

\section{DAFTAR PUSTAKA}

Burhanudin, 1988. Filsafat Pancasilaisme. PT Bina Aksara Jakarta.

Dimyati, Moh. 2006. Pendidikan Ilmu Pengetahuan dalam Kebudayaan Indonesia, Suatu Tanggungjawab moral Ilmuwan Indonesia Milenium Tiga. UNM: Malang

Latif, Muhtar, 2014. Filsafat Ilmu. PT. Prenadamedia Group. Jakarta.

Prasetio.T \& Barakatullah A.H, 2014. Filsafat, Teori dan Ilmu Hukum. PT. Gajagrafindo Jakarta

Toenlioe, A. JE, 2014. Teori dan Filsafat Pendidikan. Fakultas Ilmu Pendidikan. Malang.

Sunoto, 1991. Mengenal Filsafat Pancasila. PT Prasetia Widya Pratama. Yogyakarta 